\title{
Study of the beneficial effects of green light on lettuce grown under short-term continuous red and blue light-emitting diodes
}

\author{
Zhonghua Bian ${ }^{\mathrm{a}}$, Qichang Yang ${ }^{\mathrm{b}^{*}}$, Tao Li ${ }^{\mathrm{b}}$, Ruifeng Cheng ${ }^{\mathrm{b}}$, Yvonne Barnett ${ }^{\mathrm{a}}$ and Chungui Lu ${ }^{\mathrm{a}}{ }^{*}$
}

${ }^{a}$ School of Animal, Rural and Environmental Science, Brackenhurst Campus, Nottingham Trent University, NG25 0QF, UK

${ }^{\mathrm{b}}$ Institute of Environment of Sustainable Development in Agriculture, Chinese Academy of Agriculture Sciences, Beijing, 100081, China

\section{Correspondence \\ ${ }^{*}$ Corresponding author, \\ E-mail: chungui.lu@ntu.ac.uk; \\ E-mail: yangqichang@caas.cn}

Red and blue light are the most important light spectra for driving photosynthesis to produce adequate crop yield. It is also believed that green light may contribute to adaptations to growth. However, the effects of green light, which can trigger specific and necessary responses of plant growth, have been underestimated in the past. In this study, lettuce (Lactuca sativa L.) was exposed to different continuous light (CL) conditions for $48 \mathrm{~h}$ by a combination of red and blue light-emitting diodes (LEDs) supplemented with or without green LEDs, in an environmental-controlled growth chamber. Green light supplementation enhanced photosynthetic capacity by increasing net photosynthetic rates $\left(\mathrm{P}_{\mathrm{n}}\right)$, maximal photochemical efficiency $\left(\mathrm{F}_{\mathrm{v}} / \mathrm{F}_{\mathrm{m}}\right)$, electron transport for carbon fixation $\left(\mathrm{J}_{\mathrm{PSII}}\right)$ and chlorophyll content in plants under the CL treatment. Green light decreased malondialdehyde and $\mathrm{H}_{2} \mathrm{O}_{2}$ accumulation by increasing the activities of superoxide dismutase (SOD; EC 1.15.1.1) and ascorbate peroxidase (APX; EC 1.11.1.11) after $24 \mathrm{~h}$ of CL. Supplemental green light significantly increased the expression of photosynthetic genes $L H C b$ and PsbA from 6 to $12 \mathrm{~h}$, and these gene expression were maintained at higher levels than those under other light conditions between 12 and 24 h. However, a notable down-regulation of both $L H C b$ and PsbA was observed during 24 to $48 \mathrm{~h}$. These results indicate that the effects of green light on lettuce plant growth, via enhancing activity of

This article has been accepted for publication and undergone full peer review but has not been through the copyediting, typesetting, pagination and proofreading process, which may lead to differences between this version and the Version of Record. Please cite this article as doi: $10.1111 / \mathrm{ppl} .12713$ 
particular components of antioxidantive enzyme system and promoting of $L H C b$ and $P s b A$ expression to maintain higher photosynthetic capacity, alleviated a number of the negative effects caused by CL.

Abbreviations - APX, ascorbate peroxidase enzyme; CAT, catalase enzyme; Chl a, chlorophyll a; Chl $\mathrm{b}$, chlorophyll $\mathrm{b}$; $\mathrm{CL}$, continuous light; $\mathrm{F}_{\mathrm{v}} / \mathrm{F}_{\mathrm{m}}$, maximal photochemical efficiency of PSII; $\mathrm{F}_{\mathrm{v}}{ }^{\prime} / \mathrm{F}_{\mathrm{m}}{ }$, the efficiency of excitation capture by open PSII centres; $\mathrm{J}_{\mathrm{fD}}$, light-independent thermal dissipation and fluorescence rate; $\mathrm{J}_{\mathrm{NPQ}}$, rate of energy dissipated by light-dependent process; $\mathrm{J}_{\mathrm{PSII}}$, total electron transport rate; $\mathrm{P}_{\mathrm{n}}$, net photosynthetic rate; LEDs, light emitting diodes; LHCb, light-harvesting chlorophyll binding a/b-protein related gene; LMA, leaf mass per area; MDA, malondialdehyde; POD, peroxidase; PsbA, D1protein related gene; PSII, photosystem II; qP, photochemical quenching of PSII; $\mathrm{R} / \mathrm{B}$, red to blue light ratio.

\section{Introduction}

Light is the driving force of plant growth and development. The quantity and quality of light for photosynthesis is a combination of its duration, spectrum, and photosynthetically active radiation (Bian et al. 2015, Li and Kubota 2009). Continuous light (CL) is a potential method to increase crop production in a protected environment and is also a useful tool for speeding crop selection (Sysoeva et al. 2010, Velez-Ramirez et al. 2011). Therefore, the use of CL has been widely studied in many species, including tomato (Ohyama et al. 2005, Velez-Ramirez et al. 2014), eggplant (Murage et al. 1996), lettuce (Sysoeva et al. 2010) and pepper (Demers et al. 2002). However, CL has been shown to induce negative effects in several plant species, and the most visible negative effect induced by CL is chlorosis (Pettersen et al. 2010, Tibbitts et al. 1990). Long-term CL induces decreases in photochemical quenching (Van Gestel et al. 2005) and in the quantum yield of linear electron flux in plant leaves (Pettersen et al. 2010, Velez-Ramirez et al. 2011). Reductions in photochemical quenching and electron transport capacity not only lead to unfavourable dissipation of excess light energy but also lead to a greater propensity for light energy to generate reactive oxygen species (ROS) (Huner et al. 1998). In plants, photosystem II (PSII) is vulnerable to ROS at all light intensities, especially under excessive light stress (Murata et al. 2007), as an integral part of the reaction core of PSII, specifically the D1 protein (also known as PsbA), is sensitive to ROS generated by various abiotic stresses, such as excessive light stress, high light stress (Herbstová et al. 2012) and heat and cold stress (Sen et al. 
2014). The accumulation of ROS not only inhibits the de novo synthesis of D1 protein (Qian et al. 2009) but also can stimulate the degradation of D1 protein (Nishiyama et al. 2004). Under abiotic stress, the imbalance between the synthesis and degradation of D1 protein is the main reason leading to photodamage and decreased photosynthetic capacity in plant leaves (Sen et al. 2014). The PsbA is the key gene that encodes the D1 protein, and PsbA expression under stress is critical in the de novo synthesis of the D1 protein and the repair of photodamage of PSII (Andersson and Aro 2001). In plants, PsbA transcription is light stimulated (Klein and Mullet 1990). However, previous studies reported that short-term CL leads to decreases in PsbA transcription (DuBell and Mullet 1995, He and Vermaas 1998). Besides being modulated by light intensity and light duration, PsbA expression in plants is affected by light spectra (Bissati and Kirilovsky 2001). However, the effects of light spectra on PsbA expression in lettuce under short-term CL are still unclear.

In addition to D1 protein, the light-harvesting chlorophyll a/b-binding protein of photosystem II $(\mathrm{LHCb})$ is another important protein for maintaining high photosynthetic efficiency in plant leaves. The $\mathrm{LHCb}$ protein, which is encoded by the $\mathrm{LHCb}$ gene family, is the apoprotein of the light-harvesting complex of PSII (LHCII). LHCb collects and transfers light energy to photosynthetic reaction centres (Jansson 1999). Under abiotic stress, excessive photosynthetically active radiation can decrease $L H C b$ expression to alleviate further stress-generated damage to LHCII (Karpinski et al. 1997). Thus, the modulation of $L H C b$ expression is regarded as one of the most important mechanisms for plants to tolerate environmental stress (Ganeteg et al. 2004). However, there is limited knowledge reported in the literature on the effects of light spectra on $L H C b$ expression under CL by light-emitting diodes (LEDs).

CL-induced injury can be attributed to several environmental factors (Velez-Ramirez et al. 2011). In addition to light intensity, light spectral distribution influences the degree of injury caused by CL, but CL-induced injury is more complex than light intensity-induced injury (Demers and Gosselin 2000). Continuous red light alone or a high percentage of blue light within CL can induce severe leaf injury and reduce photosynthesis in leaves (Murage et al. 1997). However, Globig et al. (1994) reported that far-red light supplementation reduced CL-induced injury generated by red light. Regarding light spectra, red and blue light are more efficient at regulating plant physiological processes, especially photosynthetic functions (Whitelam and Hallidy 2007). However, green light has been proven to drive 
leaf $\mathrm{CO}_{2}$ fixation more efficiently than red light when combined with other light qualities, especially in strong white light (Sun et al. 1998, Terashima et al. 2009). In addition, the effect of green light on plant growth depends on the intensity of the green light (Johkan et al. 2012). Kim et al. (2004) reported that red and blue LED supplied with 24\% green light (approximately $36 \mu \mathrm{mol} \mathrm{m} \mathrm{m}^{-2} \mathrm{~s}^{-1}$ ) showed higher efficiency at facilitating lettuce growth than did other treatments that consisted of different amounts of green light. Furthermore, green light can counteract stomatal opening, stem growth modulation and chloroplast gene expression directed by red and blue light (Folta and Maruhnich 2007). Thus, we hypothesize that green light supplementation might also show positive effects on alleviating the degree of photosynthetic capacity reduction and/or injury induced by CL under red and blue light.

We previously reported that green light supplementation had beneficial effects on the growth of lettuce under short-term continuous red and blue LED light treatment (Bian et al. 2016). However, little is known about the molecular mechanisms of green light regulating photosynthetic capacity, the transcriptional control of $D 1$ - and $L H C b$-related genes, and physiological processes during short-term CL. The aims of this study were to investigate whether green light can protect lettuce from photodamage caused by $\mathrm{CL}$ and to determine whether this protection involves the gene expression of $P s b A$ and $L H C b$. The results should provide an insight into plant responses to differing light spectra and into the types of light sources to optimise plant viability, growth and yield when plants are grown in unfavourable conditions.

\section{Materials and methods}

\section{Plant materials and growth conditions}

Lettuce seeds (Lactuca sativa L. cv. Butterhead) were sown in plastic trays filled with a seed-peat mixture $(1: 1, \mathrm{v} / \mathrm{v})$ substrate and then grown in an environmental-controlled growth chamber. Fluorescent lamps (TL-D $36 \mathrm{~W}$, Philips) were used as light sources for seedling growth. The day/night temperature, photosynthetic photon flux density (PPFD), photoperiod, $\mathrm{CO}_{2}$ level, and relative humidity in the growth chamber were $25 / 20^{\circ} \mathrm{C}, 200 \mu \mathrm{mol} \mathrm{m} \mathrm{s}^{-1}, 12 \mathrm{~h}, 400 \mu \mathrm{mol} \mathrm{mol}^{-1}$ and $75 \%$, respectively. Water was added daily to maintain the moistness of the substrate and replenish evapotranspiration losses. At $14 \mathrm{~d}$ after sowing, similarly sized lettuce seedlings that had two true leaves were grown in 
40-1 containers of Hoagland solution $\left(\mathrm{pH} 6.5 \pm 0.2\right.$, EC $\left.1.9 \pm 0.1 \mathrm{dS} \mathrm{m}^{-1}\right)$. Then the plants were randomly grown under mixtures of red (R; peak wavelength: $660 \mathrm{~nm}$, peak broadness at half peak height: $15 \mathrm{~nm}$ ) and blue (B; peak wavelength: $460 \mathrm{~nm}$, peak broadness at half peak height: $15 \mathrm{~nm}$ ) LEDs $(\mathrm{R}: \mathrm{B}=4: 1)$ as well as mixtures that included green $(\mathrm{G}$; peak wavelength: $530 \mathrm{~nm}$, peak broadness at half peak height: $21 \mathrm{~nm}$ ) LEDs $(\mathrm{R}: \mathrm{B}: \mathrm{G}=1: 1: 1)$. No-reflect black separators were placed between the different light treatments to eliminate light contamination. The light spectra and PPFD were monitored daily by a spectroradiometer (Avaspec-2048CL, Avantes, Apeldoorn, The Netherlands). The PPFD was maintained at $200 \mu \mathrm{mol} \mathrm{m} \mathrm{m}^{-2}$ by adjusting the distance between the light sources and the plant canopies. To minimize the angle impact, the containers of plants under the same light sources were systematically moved every other day. The day/night temperature, PPFD, photoperiod, $\mathrm{CO}_{2}$ level and relative humidity were maintained at similar levels as those at the seedling stage. The solutions were replaced with freshly prepared solutions every $7 \mathrm{~d}$.

\section{Light treatment}

At the end of the dark period, at $20 \mathrm{~d}$ after being transplanted, the plants were transferred to the experimental conditions that consisted of a PPFD of $200 \mu \mathrm{mol} \mathrm{m} \mathrm{s}^{-2}$ and temperature of $25^{\circ} \mathrm{C}$. The plants grown under red and blue LEDs were treated with CL by red and blue LEDs as before (RB-CL, $\mathrm{R}: \mathrm{B}=4: 1$ ) or were treated with supplemental green LEDs (RBG-CL, R:B:G = 4:1:1). The plants grown under red, blue and green LEDs received CL treatment using LED light sources as before (rbg-CL, r:b:g $=1: 1: 1)$ or were treated with the same LED light sources as before but without the green light LEDs ( $\mathrm{rb}-\mathrm{CL}, \mathrm{r}: \mathrm{b}=1: 1)$. The light duration of $\mathrm{CL}$ and light intensity for all treatments were $48 \mathrm{~h}$ and $200 \mu \mathrm{mol} \mathrm{m} \mathrm{m}^{-2} \mathrm{~s}^{-1}$, respectively. The details of these treatments are summarized in Table 1. RBG-CL was used to investigate whether green light induced positive effects on the photosynthetic capacity and on PsbA and $L H C b$ expression under short-term CL versus RB-CL. rb-CL was used to investigate the effects of the red to blue light ratio $(\mathrm{R} / \mathrm{B})$ on plant photosynthetic capacity versus RB-CL and further to assay the effects of green light under CL versus rbg-CL. There were four replicates per treatment and a total of 48 plants per treatment. During the experiment, other environmental conditions were maintained at similar levels as those during the seedling stage.

\section{Leaf area and plant growth determination}


Shoot and root fresh weight, total fresh weight and leaf number of the lettuce plants were measured before $(0 \mathrm{~h})$ and after $(48 \mathrm{~h})$ treatment. The leaf area of the lettuce plants before $(0 \mathrm{~h})$ and after treatment (48 h) was determined by a portable leaf area meter (LI-3100C, LI-COR, Lincoln, NE). Leaf mass per area (LMA) was determined as the method of Fan et al. (2013). Eight plants (two plants per replicate, four replicates per light treatment) were randomly selected for each determination.

\section{Chlorophyll content measurements}

Leaf samples were collected from the second youngest and fully expanded leaves before treatment $(0$ h) and after treatment $(12,24,36$ and $48 \mathrm{~h})$. The sample leaf tissue (100 $\mathrm{mg})$ was subjected to extraction in $5 \mathrm{ml}$ of $80 \%(\mathrm{v} / \mathrm{v})$ acetone buffer at $4^{\circ} \mathrm{C}$ for $72 \mathrm{~h}$. Four replicates were performed for chlorophyll (Chl) measurements. The absorbance of the extraction solution was determined at 645 and $663 \mathrm{~nm}$ by a UV-VIS spectrophotometer (UV-180, Shimadzu, Japan). The equations described by Torrecillas et al. (1984) were used to estimate the contents of Chl a, Chl b and Chl a $+\mathrm{b}$.

\section{Antioxidantive enzyme and $\mathrm{H}_{2} \mathrm{O}_{2}$ level determination}

Fresh leaf samples collected before $(0 \mathrm{~h})$ and after $(24$ and $48 \mathrm{~h})$ treatment were immediately frozen in liquid nitrogen and stored at $-80^{\circ} \mathrm{C}$, after which they were used to determine antioxidantive enzyme and $\mathrm{H}_{2} \mathrm{O}_{2}$ levels. Leaf tissue $(0.1 \mathrm{~g})$ was ground in $1 \%(\mathrm{w} / \mathrm{v})$ polyvinylpolypyrrolidone using a chilled mortar and pestle, after which the tissue was then homogenized in $1.2 \mathrm{ml}$ of ice-cold $50 \mathrm{mM}$ phosphate buffer (pH 7.8) containing $1 \mathrm{mM}$ EDTA-Na $\mathrm{Na}_{2}$ and $0.3 \%$ Triton X-100. For ascorbate peroxidase (APX; EC 1.11.1.11) determination, $1 \mathrm{ml}$ of ascorbate was added to the mixture. The extract was centrifuged at $20000 \mathrm{~g}$ for $30 \mathrm{~min}$ at $4^{\circ} \mathrm{C}$. The supernatant, referred to as the 'crude extract', was used to determine superoxide dismutase (SOD; EC 1.15.1.1), catalase (CAT; EC 1.11.1.6) and APX enzyme activities. Four replicates were performed per measurement.

To determine the SOD activity, $3 \mathrm{ml}$ of reaction mixture containing $100 \mu \mathrm{l}$ of enzyme extract, $0.1 \mu M$ EDTA, $13 \mathrm{~m} M$ methionine, $75 \mu M$ nitro blue tetrazolium, and $2 \mu M$ riboflavin, $50 \mathrm{~m} M$ phosphate buffer ( $\mathrm{pH}$ 7.8) was shaken before being illuminated by $15-\mathrm{W}$ fluorescent lamps. The absorbance monitored at $560 \mathrm{~nm}$ was used to calculate the SOD activity. One unit of SOD activity was defined as the amount of enzyme causing 50\% inhibition of the rate of nitroblue tetrazolium chloride reduction (Wu et al. 2007). The CAT activity was determined in accordance with the methods of Bisht et al. 
(1989). The APX activity was assayed using the methods of Nakano and Asada (1981). The level of $\mathrm{H}_{2} \mathrm{O}_{2}$ was spectrophotometrically determined as described by Sergiev et al. (1997).

\section{Measurement of malondialdehyde (MDA) content}

The MDA content, as a marker of lipid peroxidation, in plant leaves was determined using the method described by Yang et al. (2010). Four replicates were measured. Leaf samples were extracted using thiobarbituric acid (TBA) and were boiled at $100^{\circ} \mathrm{C}$ for $20 \mathrm{~min}$. The supernatants were cooled to room temperature and then centrifuged at $15000 \mathrm{~g}$ for $10 \mathrm{~min}$. The absorbance monitored at 450, 532 and $600 \mathrm{~nm}$ was used to calculate the MDA content.

\section{RNA isolation and gene expression assays}

The total RNA was isolated from each sample using an RNeasy Plant Mini Kit (Qiagen) according to the manufacturer's instructions. The extracted total RNA was treated with RNase-free DNase I (Invitrogen, Carlsbad, CA) to prevent any genomic DNA contamination before reverse transcription, in accordance with the manufacturer's instructions. The total RNA was quantified using a NanoDrop $^{\mathrm{TM}}$ 2000C spectrophotometer (Thermo Fisher Scientific, Waltham, MA) before and after DNase I treatment. The quality and integrity of the total RNA were checked using electrophoresis via a 1\% agarose gel stained with SYBR green dye. The total RNA was reverse-transcribed using a RevertAid First Stand cDNA synthesis kit (Quanta Biosciences, Gaithersburg, MD) and a 20- $\mu$ l reaction mixture containing $1 \mu \mathrm{l}$ of total RNA from each individual sample. A further check for genomic DNA with cross-intron primers of PBGD was performed to ensure the cDNA in the samples did not contain genomic DNA. The cDNA fragments were then used as templates to test their transcripts. An initial denaturing temperature at $95^{\circ} \mathrm{C}$ for $30 \mathrm{~s}$, followed by 40 cycles at $95^{\circ} \mathrm{C}$ for $5 \mathrm{~s}$, $56^{\circ} \mathrm{C}$ for $30 \mathrm{~s}$ and a melt curve $65-95^{\circ} \mathrm{C}$ using a QuantiTect SYBR Green PCR Kit (Qiagen). Primers of actin were used as an internal conference.

qRT-PCR was performed independently four times, and each sample was analysed in triplicate by PCR using a 7500 Real-Time PCR System (Applied Biosystems). The quantification of gene expression was analysed by the ABI PRISM 7500 Software Tool (Applied Biosystems). Threshold values (CT) were used to quantify relative gene expression by the comparative $2^{-\Delta \Delta C T}$ method (Livak and Schmittgen 2001). 
Plants were randomly collected before treatment $(0 \mathrm{~h})$ and after treatment $(6,12,24,36$ and $48 \mathrm{~h})$. The second youngest and fully expanded leaves were used to investigate the expression of the PsbA and $L H C b$. Target gene sequences corresponding to the top BLAST hits were identified within the Compositae Genome Project EST database via sequence homology to known light absorption and transfer genes from existing Lactuca sativa L. sequence data in GenBank. Primers of the Lactuca sativa L. ACTIN gene (Accession number: AB359898.1) reported by Ebisawa et al. (2008) were used. The primers for PsbA and $L H C b$ were designed by Primer-Premier 6.0 (Biosoft International, Palo, CA). The primers used for the qRT-PCR assays are shown in Appendix S1.

\section{Gas exchange and chlorophyll fluorescence determination}

Leaf gas exchange and Chl fluorescence of the second youngest and fully expanded leaves were determined simultaneously using an integrated fluorescence fluorometer (LI-6400XT, Li-Cor, NE) before treatment $(0 \mathrm{~h})$ and after treatment $(12,24,36$ and $48 \mathrm{~h})$ as described by Weng et al. (2008). The minimal $\left(\mathrm{F}_{\mathrm{o}}{ }^{\prime}\right)$, maximal $\left(\mathrm{F}_{\mathrm{m}}{ }^{\prime}\right)$, and steady $\left(\mathrm{F}_{\mathrm{s}}\right)$ fluorescence parameters and the net photosynthetic rate $\left(\mathrm{P}_{\mathrm{n}}\right)$ were simultaneously monitored. Furthermore, the minimal $\left(\mathrm{F}_{\mathrm{o}}\right)$ and maximal $\left(\mathrm{F}_{\mathrm{m}}\right)$ fluorescence of dark-adapted leaves were measured when the leaves were dark-adapted for 30 min. During these measurements, the temperature, light intensity and $\mathrm{CO}_{2}$ concentration in the leaf chamber of the LI-6400XT were controlled at $25^{\circ} \mathrm{C}, 200 \mu \mathrm{mol} \mathrm{m} \mathrm{m}^{-2}$ and $400 \mu \mathrm{mol} \mathrm{mol}{ }^{-1}$, respectively. The actinic light in the leaf chamber was supplied by a red/blue light source. Each measurement comprised four to six replicates.

The response of electron transport and the utilization absorbed by photosystem II (PSII) were calculated in accordance with the methods of Hendrickson et al. (2004) and Maxwell and Johnson (2000). The equations for each process are described as follows: the maximal photochemical efficiency of PSII in dark-adapted leaves $\left(\mathrm{F}_{\mathrm{v}} / \mathrm{F}_{\mathrm{m}}\right)=\left(\mathrm{F}_{\mathrm{m}}-\mathrm{F}_{\mathrm{o}}\right) / \mathrm{F}_{\mathrm{m}}$; the efficiency of excitation capture by open PSII centres $\left(\mathrm{F}_{\mathrm{v}}{ }^{\prime} / \mathrm{F}_{\mathrm{m}}{ }^{\prime}\right)=\left(\mathrm{F}_{\mathrm{m}}{ }^{\prime}-\mathrm{F}_{\mathrm{o}}{ }^{\prime}\right) / \mathrm{F}_{\mathrm{m}}{ }^{\prime}$; the photochemical quenching of PSII $(\mathrm{qP})=\left(\mathrm{F}_{\mathrm{m}}{ }^{\prime}-\right.$ $\left.\mathrm{F}_{\mathrm{s}}\right) /\left(\mathrm{F}_{\mathrm{m}}{ }^{\prime}-\mathrm{F}_{\mathrm{o}}{ }^{\prime}\right)$; the quantum efficiency of PSII $\left(\Phi_{\mathrm{PSII}}\right)=\left(\mathrm{F}_{\mathrm{m}}{ }^{\prime}-\mathrm{F}_{\mathrm{s}}\right) / \mathrm{F}_{\mathrm{m}}$ '; the fraction of PSII-absorbed light energy dissipated either by light-independent thermal dissipation or by fluorescence $\left(\Phi_{\mathrm{fD}}\right)=\mathrm{F}_{\mathrm{s}} / \mathrm{F}_{\mathrm{m}}$; and the fraction of PSII-absorbed light energy is dissipated by light-dependent processes $\left(\Phi_{\mathrm{NPQ}}\right)=$ $\mathrm{F}_{\mathrm{s}} / \mathrm{F}_{\mathrm{m}}{ }^{\prime}-\mathrm{F}_{\mathrm{s}} / \mathrm{F}_{\mathrm{m}}$. 
The rate of energy dissipated by light-dependent process $\left(\mathrm{J}_{\mathrm{NPQ}}\right)$ was calculated as $\mathrm{J}_{\mathrm{NPQ}}=\Phi_{\mathrm{NPQ}} \times \mathrm{PPFD}$ $\times I_{A} \times 0.5$; the rate of light-independent thermal dissipation and fluorescence $\left(\mathrm{J}_{\mathrm{fD}}\right)$ was determined as $\mathrm{J}_{\mathrm{fD}}=\Phi_{\mathrm{fD}} \times \mathrm{PPFD} \times I_{A} \times 0.5$; the rate of total electron transport via photochemistry $\left(\mathrm{J}_{\mathrm{PSII}}\right)$ was calculated as $\mathrm{J}_{\mathrm{PSII}}=\Phi_{\mathrm{PSII}} \times \mathrm{PPFD} \times I_{A} \times 0.5$, where PPFD is the photosynthetic photon flux density, $I_{A}$ is the absorbed irradiance assuming an average leaf absorptance of 0.85 (Zhou et al. 2007), and 0.5 is the assumed proportion of absorbed quanta used by PSII reaction centres (Melis et al. 1987). The excess energy was estimated according to Demmig-Adams et al. (1996) using the equation (Excessive energy) $=(1-\mathrm{qP}) \times \mathrm{F}_{\mathrm{v}}{ }^{\prime} / \mathrm{F}_{\mathrm{m}}{ }^{\prime}$.

\section{Lincomycin treatment}

To further verify the effect of green light on lettuce growth under CL, lincomycin treatment was performed. Plants (34 days after germination) were either concomitantly exposed to CL and lincomycin $\left(0.2 \mathrm{~g} \mathrm{l}^{-1}\right)$ or without lincomycin. Lincomycin solution was prepared by dissolving lincomycin hydrochloride (Sigma Aldrich, Munich, Germany) into water. The expression of PsbA and $L H C b$ under the combined CL with lincomycin treatment was investigated. $\mathrm{F}_{\mathrm{v}} / \mathrm{F}_{\mathrm{m}}$ and the rapid light response curve (corresponding to the following light intensities: 0, 30, 50, 100, 200, 500, 800 and 1200 $\mu \mathrm{mol} \mathrm{mol}{ }^{-1}$ ) were monitored with an interval of $12 \mathrm{~h}$ using an integrated fluorescence fluorometer (LI-6800F, Li-Cor, Lincoln, NE).

\section{Statistical analysis}

All of the data were evaluated by analysis of variance (ANOVA) using SAS software (Version 8.1, SAS Institute, Cary, NC), and significant differences between means were assessed by Duncan's multiple range test at $P<0.05$.

\section{Results}

Continuous light increases shoot biomass especially when red, blue and green light are combined Before CL treatment $(0 \mathrm{~h})$, there were no significant differences in leaf area, leaf number, LMA, shoot fresh weight or total fresh weight of lettuce plants, but the root fresh weight under rb-CL (red:blue 1:1) and rbg-CL (red:blue:green 1:1:1) was lower than that under the other light treatments (Table 2). Total fresh weight, LMA, shoot and root fresh weight increased after the CL treatment for $48 \mathrm{~h}$. The 
RBG-CL (red:blue:green 4:1:1) treatment at $48 \mathrm{~h}$ showed higher fresh weight and LMA than did the rbg-CL and rb-CL treatments. The values of total fresh weight, LMA and leaf area under RBG-CL were higher than these under RB-CL (red:blue 4:1), although there were no significant differences in these parameters between RBG-CL and RB-CL. Compared with the RB-CL treatment, the RBG-CL treatment especially caused a significant increase in shoot fresh weight. In addition, leaf area under rbg-CL was higher than that under rb-CL. However, green light had little effect on leaf number and root fresh weight during $48 \mathrm{~h}$ of CL treatment (Table 2).

\section{Addition of green light alleviates the negative effect of red and blue light on chlorophyll content}

Before CL treatment $(0 \mathrm{~h})$, no significant difference was observed in Chl content among the different treatments (Fig. 1). The amounts of $\mathrm{Chl} \mathrm{a,} \mathrm{Chl} \mathrm{b}$ and $\mathrm{Chl} \mathrm{a}+\mathrm{b}$ under RB-CL and rb-CL showed constant decreases after CL treatment for $24 \mathrm{~h}$, but these decreases were markedly alleviated by adding green light to the red and blue light. Much higher amounts of chl a, Chl b and $\mathrm{Chl} \mathrm{a}+\mathrm{b}$ were observed in RBG-CL and rbg-CL than in RB-CL and rb-CL between 24 and $48 \mathrm{~h}$ (Fig. 1A-C). The Chl a to Chl $\mathrm{b}$ ratio gradually increased after $24 \mathrm{~h}$ of $\mathrm{CL}$ treatment, but the ratios under RBG-CL and rbg-CL were lower than under RB-CL and rb-CL (Fig. 1D). Furthermore, the ratio of $\mathrm{Chl}$ a to $\mathrm{Chl} b$ and contents of $\mathrm{Chl} \mathrm{a}$ and $\mathrm{Chl} \mathrm{a}+\mathrm{b}$ were higher under RBG-CL than these under rbg-CL between 24 and $48 \mathrm{~h}$ (Fig. $1 \mathrm{~A}, \mathrm{C}, \mathrm{D})$.

\section{Photosynthetic performance is improved by addition of green light}

There was no significant difference in $\mathrm{P}_{\mathrm{n}}$ under different light conditions before CL treatment $(0 \mathrm{~h})$. However, the values of $\mathrm{P}_{\mathrm{n}}$ were sharply reduced after CL for $24 \mathrm{~h}$. RBG-CL caused a marked increase in $\mathrm{P}_{\mathrm{n}}$ during the first $24 \mathrm{~h}$ of CL treatment and then a decrease from 24 to $48 \mathrm{~h}$ (Fig. 2). However, the value of $\mathrm{P}_{\mathrm{n}}$ for RBG-CL was higher than that for RB-CL. Interestingly, the treatment without green light resulted in a severe reduction in $\mathrm{P}_{n}$, as shown by the lower $\mathrm{P}_{\mathrm{n}}$ value under the rb-CL treatment. Throughout this study, the value of $\mathrm{P}_{\mathrm{n}}$ under RBG-CL was higher than that under rbg-CL, but no significant difference was observed between RB-CL and rbg-CL (Fig. 2A).

There were decreasing trends in $\mathrm{F}_{\mathrm{v}} / \mathrm{F}_{\mathrm{m}}$ and $\mathrm{F}_{\mathrm{v}}{ }^{\prime} / \mathrm{F}_{\mathrm{m}}$ ' after $24 \mathrm{~h}$ of $\mathrm{CL}$ treatment. Treatment with a higher percentage of blue light intensified the decreases in $\mathrm{F}_{\mathrm{v}} / \mathrm{F}_{\mathrm{m}}$ and $\mathrm{F}_{\mathrm{v}}{ }^{\prime} / \mathrm{F}_{\mathrm{m}}$ ' induced by the CL treatment, as 
shown by lower $\mathrm{F}_{\mathrm{v}} / \mathrm{F}_{\mathrm{m}}$ and $\mathrm{F}_{\mathrm{v}}{ }^{\prime} / \mathrm{F}_{\mathrm{m}}$ ' values under rb-CL than under RB-CL. However, green light supplementation eliminated the reduction in the $F_{v} / F_{m}$ and $F_{v}{ }^{\prime} / F_{m}$ ' values of plants exposed to $C L$ treatment (Fig. 2B, C). The $\mathrm{qP}$ under RBG-CL was higher than that under other $\mathrm{CL}$ treatments between 12 and $48 \mathrm{~h}$. Compared with the other treatments, the rb-CL treatment led to lower qP values at 36 and $48 \mathrm{~h}$ (Fig. 2D).

\section{Addition of green light promotes the electron transport and utilization}

Before the $\mathrm{CL}$ treatment $(0 \mathrm{~h})$, the level of $\mathrm{J}_{\mathrm{PSII}}$ under $\mathrm{rb}-\mathrm{CL}$ and rbg-CL was lower than that under RB-CL and RBG-CL, but there were no significant differences in $\mathrm{J}_{\mathrm{PSII}}$ among these treatments. Between 24 and $48 \mathrm{~h}$, the $\mathrm{J}_{\mathrm{PSII}}$ for RBG-CL and rbg-CL was higher than that for RB-CL and rb-CL, respectively (Fig. 3A). These results suggest that green light showed positive effects on maintaining a high $\mathrm{J}_{\mathrm{PSII}}$ under CL. The value of $\mathrm{J}_{\mathrm{fD}}$ for RBG-CL was higher than that for RB-CL, and the treatment without green light from rbg-CL caused significant decreases in $\mathrm{J}_{\mathrm{fD}}$. There was no significant difference in $\mathrm{J}_{\mathrm{fD}}$ between RB-CL and rb-CL except at $0 \mathrm{~h}$, suggesting that a change in R/B had little effect on $\mathrm{J}_{\mathrm{fD}}$ under the CL treatment (Fig. 3B).

Unlike $\mathrm{J}_{\mathrm{fD}}$, RBG-CL had a lower $\mathrm{J}_{\mathrm{NPQ}}$ than did RB-CL at 12 and $36 \mathrm{~h}$, but this parameter for rb-CL was higher than that for rbg-CL between 12 and $48 \mathrm{~h}$. The highest value of $\mathrm{J}_{\mathrm{NPQ}}$ was observed under rb-CL, followed by RB-CL, RBG-CL and then rbg-CL during the period from 24 to $48 \mathrm{~h}$ (Fig. 3C). Except RBG-CL, the CL treatments caused excessive energy accumulation in the leaves. The level of excessive energy for RBG-CL showed a constant deceasing trend between 0 and $36 \mathrm{~h}$ before reaching the same level as that at $0 \mathrm{~h}$ again at $48 \mathrm{~h}$. Interestingly, the levels of excessive energy in plants under RBG-CL and rbg-CL were lower than those under RB-CL and rb-CL, respectively (Fig. 3D).

\section{Green light supplementation enhances antioxidantive enzyme activity}

The activities of the antioxidantive enzymes and $\mathrm{H}_{2} \mathrm{O}_{2}$ levels in lettuce leaves are presented in Fig. 4. The SOD activity for the RBG-CL treatment was higher than that for the other treatments at 24 and 48 h. However, no significant differences were observed in SOD activity between rb-CL and rbg-CL (Fig. 4A). The CAT activity for RBG-CL remained steady during the $48 \mathrm{~h}$ of CL. However during the same period, this parameter for other treatments showed an increasing trend, and the values were higher

This article is protected by copyright. All rights reserved. 
than those for RBG-CL at $48 \mathrm{~h}$ (Fig. 4B). Unlike the CAT activity, the highest APX activity was obtained under RBG-CL, followed by rbg-CL, RB-CL and then rb-CL at 24 and 48 h. (Fig. 4C). There was an increasing trend in $\mathrm{H}_{2} \mathrm{O}_{2}$ levels during the $48 \mathrm{~h}$ of $\mathrm{CL}$ treatment. However, green light supplementation showed positive effects on alleviating $\mathrm{H}_{2} \mathrm{O}_{2}$ accumulation in lettuce leaves under the CL treatment, as shown by the lower $\mathrm{H}_{2} \mathrm{O}_{2}$ levels for RBG-CL and rbg-CL at 24 and 48 h. (Fig. 4D).

\section{Addition of green light alleviates the negative effect of red and blue light on lipid peroxidation}

Lipid peroxidation was revealed by the malondialdehyde (MDA) content in the lettuce leaves. CL for $48 \mathrm{~h}$ resulted in a constantly increasing MDA content. Green light supplementation slowed the increase in MDA content, but the lack of green light from the light source led to a significant accumulation in MDA content, as shown by higher MDA contents in the leaves under RB-CL and rb-CL than under RBG-CL and rbg-CL, respectively. Furthermore, the MDA content under rb-CL was higher than that under RB-CL after CL for $24 \mathrm{~h}$. This finding indicates that high percentage of blue light in the CL treatment led to severe lipid peroxidation (Fig. 5).

\section{Green light supplementation up-regulates PsbA and $L H C b$ expression}

Both the transcripts of PsbA and $L H C b$ were down-regulated after $24 \mathrm{~h}$ of $\mathrm{CL}$ treatment compared with transcript levels at $0 \mathrm{~h}$ of $\mathrm{CL}$ treatment, but green light supplementation alleviated this down-regulation. A decrease of $\mathrm{R} / \mathrm{B}$ in $\mathrm{CL}$ treatment intensified the down-regulation of the PsbA, as shown by the higher PsbA expression under RB-CL than under rb-CL (Fig. 6A). However, there was no significant difference in the expression of the LHCb between rb-CL and RB-CL (Fig. 6B). When the plants under CL were supplied with green light, the expression of the PsbA was up-regulated between 12 and $24 \mathrm{~h}$, and the transcript of the $L H C b$ was up-regulated between 6 and $24 \mathrm{~h}$. The expressions of the PsbA and $L H C b$ both peaked at $12 \mathrm{~h}$ under RBG-CL (Fig. 6A, B).

\section{Green light can partially reverse the inhibitory effect of lincomycin on the photosystem II efficiency}

Lincomycin-treated plants showed a significant decrease in maximal photochemical efficiency $\left(\mathrm{F}_{\mathrm{v}} / \mathrm{F}_{\mathrm{m}}\right)$ under RB-CL and RBG-CL after $6 \mathrm{~h}$, but interestingly, the value of $\mathrm{F}_{\mathrm{v}} / \mathrm{F}_{\mathrm{m}}$ with RBG-CL treated in the 
presence of lincomycin was 10-45\% higher than that of RB-CL (Fig. S1). This suggested that green light plays an important role in maintaining a higher PSII efficiency and protecting against photoinhibition, even when the D1 synthesis is blocked by lincomycin. The light response curve experiments indicated light-induced damage of photosystem II. However, the effect of the inhibition was partly relieved by green light during 6-24 h (Fig. S2). For PsbA gene expression, no significant difference was found between lincomycin treated and non-lincomycin treated plants under same light condition (RB-CL or RBG-CL), but RBG-CL combined with lincomycin treatment (RBG-CL-linc) resulted in higher gene expression than under RB-CL-linc, and the highest expression strength was observed during 12-24 h. (Fig. S3A). In addition, lincomycin-treated plants exhibited a significant decrease of $L H C b$ gene expression compared to plants without lincomycin treatment. RBG-CL-linc showed a higher level expression of $L H C b$ than RB-CL-linc during 6-24 h light (Fig. S3B).

\section{Discussion}

\section{Green light increases plant growth by maintaining a higher photosynthetic capacity}

Light is one of the most important factors affecting plant growth and development. The contribution of green light to plant growth and development has been proven in many species, especially in Arabidopsis thaliana (Kudo et al. 2009, Wang and Folta 2013, Zhang et al. 2011). In the present study, we found that green light played a positive role in lettuce growth under CL conditions. CL can lead to reductions in photosynthetic capacity and maximum electron transport rates (Pettersen et al. 2010, Van Gestel et al. 2005). In general, $\mathrm{F}_{\mathrm{v}} / \mathrm{F}_{\mathrm{m}}, \mathrm{F}_{\mathrm{v}}{ }^{\prime} / \mathrm{F}_{\mathrm{m}}{ }^{\prime}$ and $\mathrm{qP}$ are parameters that reflect photochemical quenching in PSII (Baker 2008). The long-term decrease of $F_{v} / F_{m}$ reflected the rate of PSII-damage and is an indicator for photo-inhibition. In this study, the levels of $F_{v} / F_{m}, F_{v}{ }^{\prime} / F_{m}{ }^{\prime}$ and $q P$ were all reduced by $\mathrm{CL}$, but these decreases were alleviated or even absent after adding green light to red and blue LED light (Fig. 2B-D). Treating plants with specific inhibitors of the chloroplastic translation, such as lincomycin, also can block the PSII repair process, especially D1 protein synthesis in the chloroplast (Ding et al. 2012, Mulo et al. 2003, Kato et al. 2015, Tian et al. 2017). In this study, it was shown that the positive effect of green light on alleviating $\mathrm{F}_{\mathrm{v}} / \mathrm{F}_{\mathrm{m}}$ was still observed after treatment with lincomycin under CL (Fig. S1). This finding suggested that green light supplementation can reduce the photo-inhibition by alleviating the PSII damage and improving the photochemical efficiency in lettuce exposed to CL from red and blue LEDs. A previous study also proved that green light supplementation 
was more efficient at promoting $\mathrm{J}_{\mathrm{PSII}}$ to drive photosynthesis in sunflower leaves (Helianthus annuus) (Terashima et al. 2009).

\section{Green light alleviates injury caused by continuous light}

CL has positive effects on increasing the productivity of plant species, including Arabidopsis (Lepistö et al. 2009), lettuce (Gaudreau et al. 1994) and some potato cultivars (Wheeler et al. 1986). However, CL also induces injury and damages plants (Velez-Ramirez et al. 2011). Under stress conditions, the accumulated excess energy in plant leaves leads to the generation of ROS (Cakmak and Kirkby 2008), and photo-oxidative damage caused by ROS is responsible for chlorosis and membrane lipid peroxidation (Sevengor et al. 2011). Globig et al. (1994) reported that adding far-red light to red light can reduce the CL injury caused by red light alone. In nature, green light accounts for a large percentage of solar light. If CL is partially or completely provided by solar light, the injury is less than that caused by CL from artificial light sources or is even absent (Demers and Gosselin 2000). This study confirms that in addition to far-red light, green light also has a positive effect on reducing the injury caused by CL via red and blue LEDs. The data produced by this study demonstrate that green light supplementation can alleviate Chl decrease by increasing activities of SOD and APX to scavenge ROS generated by CL, as shown by the higher Chl content, SOD and APX activities and lower $\mathrm{H}_{2} \mathrm{O}_{2}$ under RBG-CL and rbg-CL. However, Haque et al. (2105) reported that CL for $12 \mathrm{~d}$ did not affect APX activity in tomato plant leaves. Furthermore, the significant differences in above-mentioned parameters between RBG-CL and rbg-CL indicates that under CL treatment, the effect of green light on regulating lettuce growth and development is subjected to its percentage in the total light spectra. A similar result in lettuce was reported previously by Kim et al. (2004).

\section{Green light supplementation increases photosynthetic capacity by promoting the expression of PsbA and $L H C b$}

In plants, repairing photodamage of PSII is important for alleviating photo-inhibition and for maintaining high photosynthetic capacity in plants under abiotic stress (Zavafer et al. 2015). The transcript of PsbA is critical for both the de novo synthesis of the D1 protein and the repair of photodamage of PSII (Andersson and Aro 2001). Down-regulation of the PsbA transcript can lead to photo-inhibition (Murata et al. 2007, Sen et al. 2014) and cause $P_{n}$ reduction (Powles 1984). The 
expression of the PsbA was down-regulated after CL for more than $24 \mathrm{~h}$ (Fig. 6A). The decrease in $\mathrm{P}_{\mathrm{n}}$ under RB-CL and rb-CL might be caused by the down-regulation of the PsbA. However, green light supplementation up-regulated PsbA expression at 12 and $24 \mathrm{~h}$ and alleviated the down-regulation of the PsbA caused by long durations of CL (Fig. 6A). In this study, lincomycin treatment flattened the slope of the linear portion of the photosynthesis response curve to light, even under green light supplement treatment (Fig. S2), reflecting the inactivation and/or disassembly of PSII cores, especially the D1 protein (Adams et al. 2008). Since green light supplement showed strong effect on PsbA expression under CL in lincomycin-treated plants (Fig. S3A), it was suggested that green light could promote the de novo synthesis of D1 protein by stimulating the expression of the PsbA to repair the photodamage of PSII caused by CL, thereby maintaining a higher photosynthetic capacity. This phenomenon could partly explain why the addition of green light led to an increase in $\mathrm{P}_{\mathrm{n}}$ during the first $24 \mathrm{~h}$ and alleviated the reduction in $\mathrm{P}_{\mathrm{n}}$ caused by CL (Fig. 2A). The positive effect of green light on promoting PsbA expression was also reported by Efimova et al. (2013). Furthermore, compared with rbg-CL, the significant higher psbA transcript for RBG-CL suggests that the positive effect of green light on PsbA expression depends on the percentage of green light in the total light spectra of CL.

$\mathrm{LHCb}$, encoded by the $L H C b$ gene, is essential for the regulation and distribution of excitation energy within the photosynthetic apparatus (Melis 1996). In the present study, plants under green light supplementation produced significantly more $L H C b$ transcripts (Fig. 6B), which perform two important functions: a higher efficient collection of light energy for photosynthesis and a higher capacity of dissipating excessive excitation energy from PSII (Fan et al. 2011, Kong et al. 2016). This view was further supported by the evidence of down-regulation of $L H C b$ transcripts under lincomycin treatment (Fig. S3B) and the concomitant decrease in maximum of $\mathrm{J}_{\mathrm{PSII}}$ (Fig. S2) under green light supplementation. Similar results were also reported in Arabidopsis by Dhingra et al. (2006). Furthermore, the changes in $\mathrm{J}_{\mathrm{PSII}}, \mathrm{J}_{\mathrm{fD}}$ and $\mathrm{J}_{\mathrm{NPQ}}$ among CL treatments led to different accumulations of excess energy in the lettuce leaves (Fig. 3D). Excessive energy in leaves causes reduced $L H C b$ expression under abiotic stress (Ganeteg et al. 2004, Karpinski et al. 1997). In this sense, the higher LHCb expression under RBG-CL might be a consequence of lower excess energy in lettuce leaves compared with rbg-CL (Fig. 6B). 
With increased light duration, CL led to the accumulation of excessive energy in plant leaves (Fig. 3D). Under excessive light conditions, more absorbed light energy is used for generating ROS (Huner et al. 1998). After CL for $36 \mathrm{~h}$, the down-regulation of PsbA and $L H C b$ expression and the rapid accumulation of MDA and $\mathrm{H}_{2} \mathrm{O}_{2}$ in plants indicate an excessive accumulation of ROS induced by $\mathrm{CL}$ led to membrane lipid peroxidation and the down-regulation of PsbA (He and Vermaas 1998, Qian et al. 2009) and LHCb (Mackerness et al. 1999). CL is a type of environmental stress that disturbs the natural photoperiod of plants and interferes with their inherent circadian rhythm and gene expression (Velez-Ramirez et al. 2011). Green light supplementation has been proven to promote shade avoidance-related gene expression, and cryptochrome receptors participate in the acclimation to green light-enriched environments (Zhang et al. 2011). Under CL, green light can also affect the gene expression of blue and red light photoreceptor genes (Folta and Maruhnich 2007). Therefore, further studies and genetic analyses on the expression of major circadian clock genes (e.g. CCA1, LHY and TOC1) and photoreceptor genes (e.g. $P H Y B$ and $C R Y 1$ ) together with enzyme activity analyses during either natural stress (e.g. high light and high temperature) or CL will help us understand more about the regulation of green light on plant growth and development. Given the available plant genomes and recent advances in RNA-Seq as a method of transcriptome profiling, it is possible to expand our understanding of the regulatory mechanisms controlling plant growth by LED light.

\section{Conclusion}

$\mathrm{CL}$ for more than $24 \mathrm{~h}$ in the presence of red and blue light led to membrane lipid peroxidation of mesophyll cells and reduced the photosynthetic capacity in lettuce leaves, but green light supplementation enhanced antioxidantive enzyme activities to alleviate these negative effects. Green light supplementation enhanced electron transport for carbon fixation $\left(\mathrm{J}_{\mathrm{PSII}}\right)$ and promoted lettuce growth under CL treatment. CL with red and blue LEDs led to the down-regulation of the PsbA and $L H C b$ transcripts, but green light supplementation facilitated the expressions of the $P s b A$ and $L H C b$ to maintain a higher photosynthetic capacity in lettuce. Furthermore, green light can still induce PsbA gene expression, when lincomycin blocks the PSII repair process by inhibiting D1 protein synthesis. Therefore, our study confirms that green light plays a positive role in plant processes and the regulation of photosynthetic genes. As such, green light could be used to stimulate photosynthetic capacity and other critical features to enhance photosynthesis during key stages under light stress 
conditions and/or other photosynthetically unfavourable conditions.

\section{Author contributions}

Z. B. conducted the measurements and performed the data analysis. Z. B., T. L. and R. C. prepared the manuscript. C. L., Y. B. and Q. Y. made substantial contributions to the conception and experimental design and critically revised the manuscript.

Acknowledgements - This work was performed under support from Innovate UK, Agri-Tech Catalyst (131784) and Nottingham Trent University Materials Research Seedcorn Fund. This work was financially supported by the National High Technology Research and Development Program of China (863 Project, Grant No. 2013AA103004).

\section{References}

Andersson B, Aro EM (2001) Photodamage and D1 protein turnover in photosystem II. In: Advances in Photosynthesis and Respiration: Regulation of Photosynthesis. Kluwer Academic, Dordrecht, pp 377-393

Adams WW, Zarter CR, Mueh KE, Amiard V, Demmig-Adams B (2006) Energy dissipation and photoinhibition: A continuum of photoprotection. In Photoprotection, Photoinhibition, Gene regulation, and Environment. In: Demmig-Adams B, Adams WW, Mattoo AK (eds)). Springer Netherlands, Netherlands, pp. 49-64

Baker NR (2008) Chlorophyll fluorescence: a probe of photosynthesis in vivo. Annu Rev Plant Biol 59: $89-113$

Bian ZH, Yang QC, Liu WK (2015) Effects of light quality on the accumulation of phytochemicals in vegetables produced in controlled environments: a review. J Sci Food Agri 95: 869-877

Bian ZH, Cheng RF, Yang QC, Wang J, Lu CG (2016) Continuous light from red, blue, and green Light-emitting diodes reduces nitrate Content and enhances phytochemical concentrations and antioxidant capacity in lettuce. J Amer Soc Hort Sci 141: 186-192

Bisht SS, Sharma A, Chaturvedi K (1989) Certain metabolic lesions of chromium toxicity in radish. Indian J Agric Biochem 2: 109-115 
Bissati EK, Kirilovsky D (2001) Regulation of $p s b A$ and $p s a E$ expression by light quality in Synechocystis species PCC 6803. A redox control mechanism. Plant Physiol 125: 1988-2000

Cakmak I, Kirkby EA (2008) Role of magnesium in carbon partitioning and alleviating photooxidative damage. Physiol Plant 133: 692-704

Demers DA, Gosselin A (2002) Growing greenhouse tomato and sweet pepper under supplemental lighting: optimal photoperiod, negative effects of long photoperiod and their causes. Acta Hort 580: $83-88$

Demmig-Adams B, Adams III W, Barker D, Logan B, Bowing D, Verhoeven A (1996) Using chlorophyll fluorescence to assess the fraction of absorbed light allocated to thermal dissipation of excess excitation. Physiol Plant 98: 253-264

Dhingra A, Bies DH, Lehner KR, Folta KM (2006) Green light adjusts the plastid transcriptome during early photomorphogenic development. Plant Physiol 142: 1256-1266

Dubell AN, Mullet JE (1995) Differential transcription of pea chloroplast genes during light-induced leaf development (continuous far-red light activates chloroplast transcription). Plant Physiol 109: $105-112$

Ding S, Lei M, Lu Q, Zhang A, Yin Y, Wen X, Zhang L, Lu C (2012). Enhanced sensitivity and characterization of photosystem II in transgenic tobacco plants with decreased chloroplast glutathione reductase under chilling stress. Biochim Biophys Acta (BBA)-Bioenergetics 1817:1979-1991

Ebisawa M, Shoji K, Kato M, Shimomura K, Goto F, Yoshihara T (2008) Supplementary ultraviolet radiation $\mathrm{B}$ together with blue light at night increased quercetin content and flavonol synthase gene expression in leaf lettuce (Lactuca sativa L.). Environ Control Biol 46: 1-11

Efimova MV, Karnachuk RA, Kusnetsov VV, Kuznetsov VV (2013) Green light regulates plastid gene transcription and stimulates the accumulation of photosynthetic pigments in plants. Doklady Biol Sci 451: 253-256

Fan XX, Xu ZG, Liu XY, Tang CM, Wang LW, Han XL (2013) Effects of light intensity on the growth and leaf development of young tomato plants grown under a combination of red and blue light. Sci Hort 153: 50-55

Fan P, Feng J, Jiang P, Chen X, Bao H, Nie L, Jiang D, Lv S, Kuang TY, Li YX (2011) Coordination of carbon fixation and nitrogen metabolism in Salicornia europaea under salinity: comparative 
proteomic analysis on chloroplast proteins. Proteomics 11: 4346-4367

Folta KM, Maruhnich SA (2007) Green light: a signal to slow down or stop. J Exp Bot 58: 3099-3111

Ganeteg U, Külheim C, Andersson J, Jansson S (2004) Is each light-harvesting complex protein important for plant fitness? Plant Physiol 134: 502-509

Gaudreau L, Charbonneau J, Vézina LP, Gosselin A (1994) Photoperiod and photosynthetic photon flux influence growth and quality of greenhouse-grown lettuce. HortScience 29: 1285-1289

Globig S, Rosen I, Janes HW (1994) Continuous light effects on photosynthesis and carbon metabolism in tomato, Acta Hort 418: 141-152

Haque MS, Kjaer KH, Rosenqvist E, Ottosen CO (2015) Continuous light increases growth, daily carbon gain, antioxidants, and alters carbohydrate metabolism in a cultivated and a wild tomato species. Front Plant Sci 6: 522

He QF, Vermaas W (1998) Chlorophyll a availability affects psbA translation and D1 precursor processing in vivo in Synechocystis sp. PCC 6803. Proc Natl Acad Sci USA 95: 5830-5835

Hendrickson L, Förster B, Furbank RT, Chow WS (2004) Processes contributing to photoprotection of grapevine leaves illuminated at low temperature. Physiol Plant 121: 272-281

Herbstová M, Tietz S, Kinzel C, Turkina MV, Kirchhoff H (2012) Architectural switch in plant photosynthetic membranes induced by light stress. Proc Natl Acad Sci USA 109: 20130-20135

Huner NPA, Öquist G, Sarhan F (1998) Energy balance and acclimation to light and cold. Trends Plant Sci 3: 224-230Jansson S (1999) A guide to the Lhc genes and their relatives in Arabidopsis. Trends Plant Sci 4: 236-240

Johkan M, Shoji K, Goto F, Hahida S, Yoshihara T (2012) Effect of green light wavelength and intensity on photomorphogenesis and photosynthesis in Lactuca sativa. Environ Exp Bot 75: $128-133$

Kato Y, Ozawa S, Takahashi Y, Sakamoto W (2015) D1 fragmentation in photosystem II repair caused by photo-damage of a two-step model. Photosynth Res 126: 409-416

Karpinski S, Karpinska B, Creissen G, Mullineauxa PM (1997) Photosynthetic electron transport regulates the expression of cytosolic ascorbate peroxidase genes in Arabidopsis during excess light stress. The Plant Cell 9: 627-640

Kim HH, Goins GD, Wheeler RM, Sager JC (2004) Green-light supplementation for enhanced lettuce growth under red- and blue-light-emitting diodes. HortScience 39: 1617-1622 
Klein RR, Mullet JE (1990) Light-induced transcription of chloroplast genes. psbA transcription is differentially enhanced in illuminated barley. J Biol Chem 265: 1895-1902

Kong XQ, Luo Z, Dong HZ, Eneji AE, Li WJ (2016) $\mathrm{H}_{2} \mathrm{O}_{2}$ and ABA signaling are responsible for the increased Nap efflux and water uptake in Gossypium hirsutum L. roots in the non-saline side under non-uniform root zone salinity. J Exp Bot 67: 2247-2261

Kudo R, Ishida Y, Yamamoto K (2009) Effects of green light irradiation on induction of disease resistance in plants. Acta Hort 907: 251-254

Lepistö A, Kangasjärvi S, Luomala EM, Brader G, Sipari N, Keränen M, Keinänen M, Rintamäki E (2009) Chloroplast NADPH-thioredoxin reductase interacts with photoperiodic development in Arabidopsis. Plant Physiol 149: 1261-1276

Li Q, Kubota C (2009) Effects of supplemental light quality on growth and phytochemicals of baby leaf lettuce. Environ Exp Bot 67: 59-64

Livak KJ, Schmittgen TD (2001). Analysis of relative gene expression data using real-time quantitative PCR and the $2^{-\Delta \Delta C T}$ method. Methods 25: 402-408

Mackerness SAH, Jordan BR, Thomas B (1999) Reactive oxygen species in the regulation of photosynthetic genes by ultraviolet-B radiation (UV-B: $280-320 \mathrm{~nm}$ ) in green and etiolated buds of pea (Pisum sativum L.). J Photochem Photobiol 48: 180-188

Maxwell K, Johnson GN (2000) Chlorophyll fluorescence - a practical guide. J Exp Bot 51: 659-668

Melis A (1996) Excitation energy transfer: functional and dynamic aspects of Lhc (cab) proteins. In: Ort DR, Yocum CF (eds) Advances in Photosynthesis. Kluwer Academic Publishers, Dordrecht, pp 523-538

Melis A, Spangfort M, Andersson B, (1987) Light-absorption and electron-transport balance between photosystem II and photosystem I in spinach chloroplasts. Photochem Photobiol 45: 129-136

Murage EN, Watashiro N, Masuda M (1997) Influence of light quality, PPFD and temperature on leaf chlorosis of eggplants grown under continuous illumination. Sci Hortic 68: 73-82

Murage EN, Watashiro N, Masuda M (1996) Leaf chlorosis and carbon metabolism of eggplant in response to continuous light and carbon dioxide. Sci Hortic 67: 27-37

Murata N, Takahashi S, Nishiyama Y, Allakhverdiev SI (2007) Photoinhibition of photosystem II under environmental stress. Biochim Biophys Acta 1767: 414-421 
Mulo P, Pursiheimo S, Hou C X, Tyystjärvi T, Aro E M (2003) Multiple effects of antibiotics on chloroplast and nuclear gene expression. Funct Plant Biol 30: 1097-1103

Nakano Y, Asada K (1981) Hydrogen peroxide is scavenged by ascorbate-specific peroxidase in spinach chloroplasts. Plant Cell Physiol 22: 867-880

Nishiyama Y, Allakhverdiev SI, Yamamoto H, Hayashi H, Murata N (2004) Singlet oxygen inhibits the repair of photosystem II by suppressing the translation elongation of the D1 protein in Synechocystis sp. PCC 6803. Biochemistry 43: 11321-11330

Ohyama K, Manabe K, Omura Y, Kozai T, Kubota C (2005) Potential use of a 24-hour photoperiod (continuous light) with alternating air temperature for production of tomato plug transplants in a closed system. HortScience 40: 374-377

Pettersen RI, Torre S, Gislerød HR (2010) Effects of leaf aging and light duration on photosynthetic characteristics in a cucumber canopy. Sci Hortic 125: 82-87

Powles SB (1984) Photoinhibition of photosynthesis induced by visible light. Annu Rev plant physiol 35: $15-44$

Qian HF, Li JJ, Sun LW, Chen W, Sheng GD, Liu WP, Fu ZW (2009) Combined effect of copper and cadmium on Chlorella vulgaris growth and photosynthesis-related gene transcription. Aquatic Toxicol 94: 56-61

Sen G, Eryilmaz IE, Ozakca D (2014) The effect of aluminium-stress and exogenous spermidine on chlorophyll degradation, glutathione reductase activity and the photosystem II D1 protein gene (psbA) transcript level in lichen Xanthoria parietina. Phytochemistry 98: 54-59

Sergiev I, Alexieva V, Karanov E (1997) Effect of spermine, atrazine and combination between them on some endogenous protective systems and stress markers in plants. Compt Rend Acad Bulg Sci 51: $121-124$

Sevengor S, Yasar F, Kusvuran S, Ellialtioglu S (2011) The effect of salt stress on growth, chlorophyll content, lipid peroxidation and antioxidative enzymes of pumpkin seedling. Afr J Agr Res 6: $4920-4924$

Sun JD, Nishio JN, Vogelmann TC (1998) Green light drives $\mathrm{CO}_{2}$ fixation deep within leaves. Plant Cell Physiol 39: 1020-1026

Sysoeva MI, Markovskaya EF, Shibaeva TG (2010) Plant under continuous light: a review. Plant Stress 4: 5-17

This article is protected by copyright. All rights reserved. 
Terashima I, Fujita T, Inoue T, Chow WS, Oguchi R (2009) Green light drives leaf photosynthesis more efficiently than red light in strong white light: revisiting the enigmatic question of why leaves are green. Plant Cell Physiol 50: 684-697

Tian YL, Ungerer P, Zhang HY, Ruban AV (2017) Direct impact of the sustained decline in the photosystem II efficiency upon plant productivity at different developmental stages. J Plant Physiol 212: 45-53

Tibbitts TW, Bennett SM, Cao WX (1990) Control of continuous irradiation injury on potatoes with daily temperature cycling. Plant Physiol 93: 409-411

Torrecillas A, Leon A, Del Amor F, Martinez-Monpean MC (1984) Determinacion rapida de clorofila en discos foliares de limonero. Fruits 39: 617-622

Van Gestel NC, Nesbit AD, Gordon EP, Green C, Paré PW, Thompson L, Peffley EB, Tissue DT (2005) Continuous light may induce photosynthetic downregulation in onion-consequences for growth and biomass partitioning. Physiol Plant 125: 235-246

Velez-Ramirez AI, van Ieperen W, Vreugdenhil D, Millenaar FF (2011) Plants under continuous light. Trends Plant Sci 16: 310-318

Velez-Ramirez AI, van Ieperen W, Vreugdenhil D, van Poppel PM, Heuvelink E, Millenaar, FF (2014) A single locus confers tolerance to continuous light and allows substantial yield increase in tomato. Nat Commun 5: 4549

Wang YH, Folta KM (2013) Contributions of green light to plant growth and development. Amer J Bot 100: 70-78

Weng XY, Xu HX, Yang Y, Peng HH (2008) Water-water cycle involved in dissipation of excess photon energy in phosphorus deficient rice leaves. Biol Plant 52: 307-313

Wheeler RM, Tibbitts TW (1986) Growth and tuberization of potato (Solanum tuberosum L.) under continuous light. Plant Physiol 80: 801-804

Whitelam GC, Hallidy KJ (2007) Light and plant development. Blackwell Publishing Ltd, Oxford

Wu CH, Tewari RK, Hahn EJ, Paek KY (2007) Nitric oxide elicitation induces the accumulation of secondary metabolites and antioxidant defense in adventitious roots of Echinacea purpurea. $\mathrm{J}$ Plant Biol 50: 636-643

Yang F, Wang Y, Miao LF (2010) Comparative physiological and proteomic responses to drought stress in two poplar species originating from different altitudes. Physiol Plant 139: 388-400 
Zavafer A, Cheah MH, Hillier W, Chow WS, Takahashi S (2015) Photodamage to the oxygen evolving complex of photosystem II by visible light. Sci Rep 5: 16363

Zhang TT, Maruhnich SA, Folta KM (2011) Green light induces shade avoidance symptoms. Plant Physiol 157: 1528-1536

Zhou YH, Lam HM, Zhang JH (2007) Inhibition of photosynthesis and energy dissipation induced by water and high light stresses in rice. J Exp Bot 58: 1207-1217

\section{Supporting Information}

Appendix S1. Primers used during this study.

Fig. S1. The maximum photosynthetic efficiency in dark-adapted leaves $\left(\mathrm{F}_{\mathrm{v}} / \mathrm{F}_{\mathrm{m}}\right)$ of leaves in response to continuous light (CL) treatment with/without lincomycin (linc).

Fig. S2. The $\mathrm{J}_{\mathrm{PSII}}$ of lettuce plants under continuous light (CL) treated with/without lincomycin (linc).

Fig. S3. Expression levels of the PsbA (A) and $L H C b$ (B) in response to continuous light (CL) treated with/without lincomycin (linc). 


\section{Figure legends}

Fig. 1. Changes in the contents of chlorophyll (Chl) a (A), Chl b (B) and $\mathrm{Chl} \mathrm{a}+\mathrm{b}(\mathrm{C})$ and in the ratio of $\mathrm{Chl}$ a to $\mathrm{Chl} b(\mathrm{D})$ under continuous light (CL). Data points indicate the mean $\pm \mathrm{SE}(\mathrm{n}=4)$
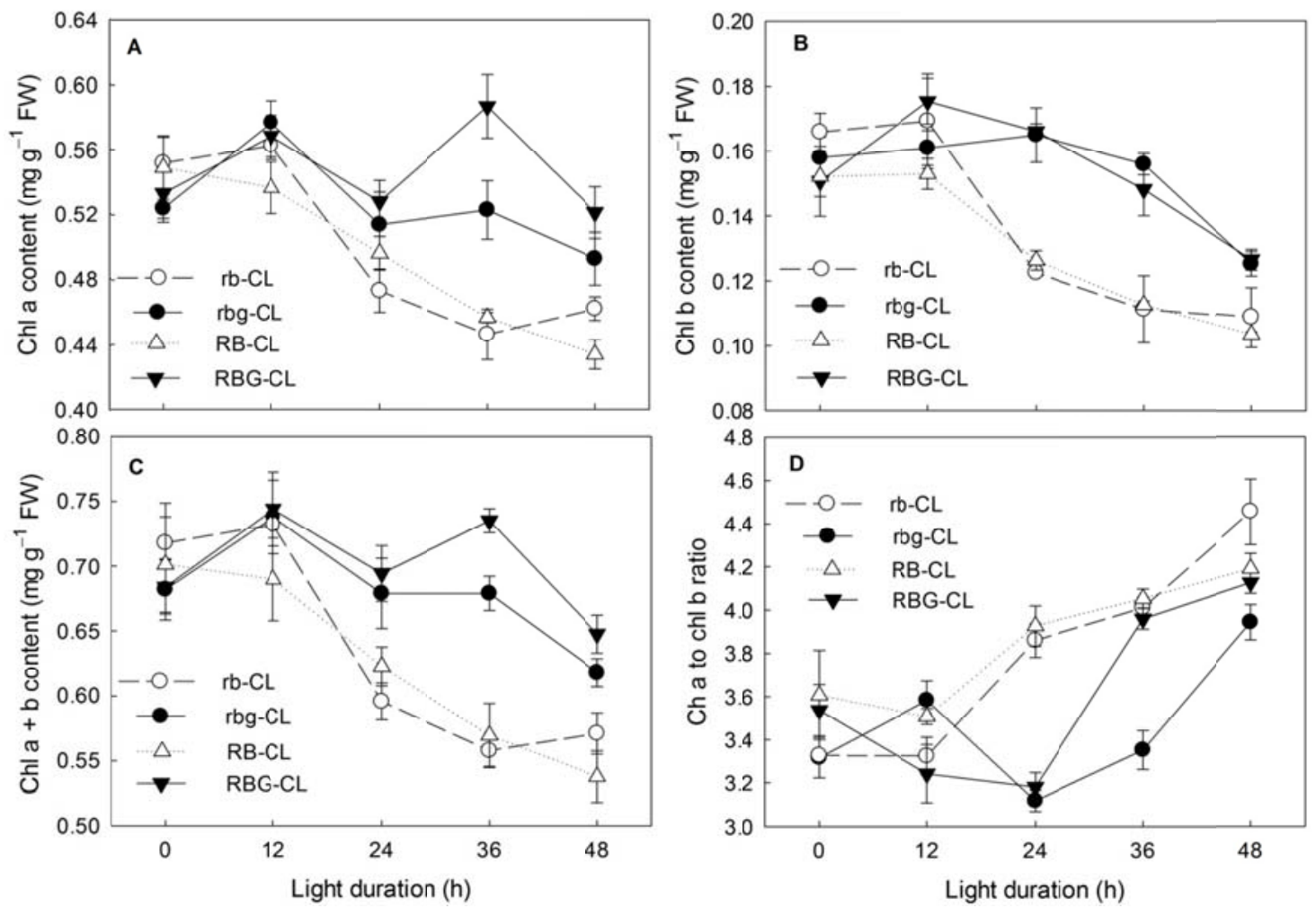

Fig. 2. Net photosynthetic rate $\left(\mathrm{P}_{\mathrm{n}}, \mathrm{A}\right)$, maximum photosynthetic efficiency in dark-adapted leaves $\left(\mathrm{F}_{\mathrm{v}} / \mathrm{F}_{\mathrm{m}}, \mathrm{B}\right)$ and in light-adapted leaves $\left(\mathrm{F}_{\mathrm{v}}{ }^{\prime} / \mathrm{F}_{\mathrm{m}}, \mathrm{C}\right)$ and photochemical quenching (qP, D) of leaves in response to continuous light $(C L)$. Data points indicate the mean $\pm S E(n=4$ or 6$)$. 

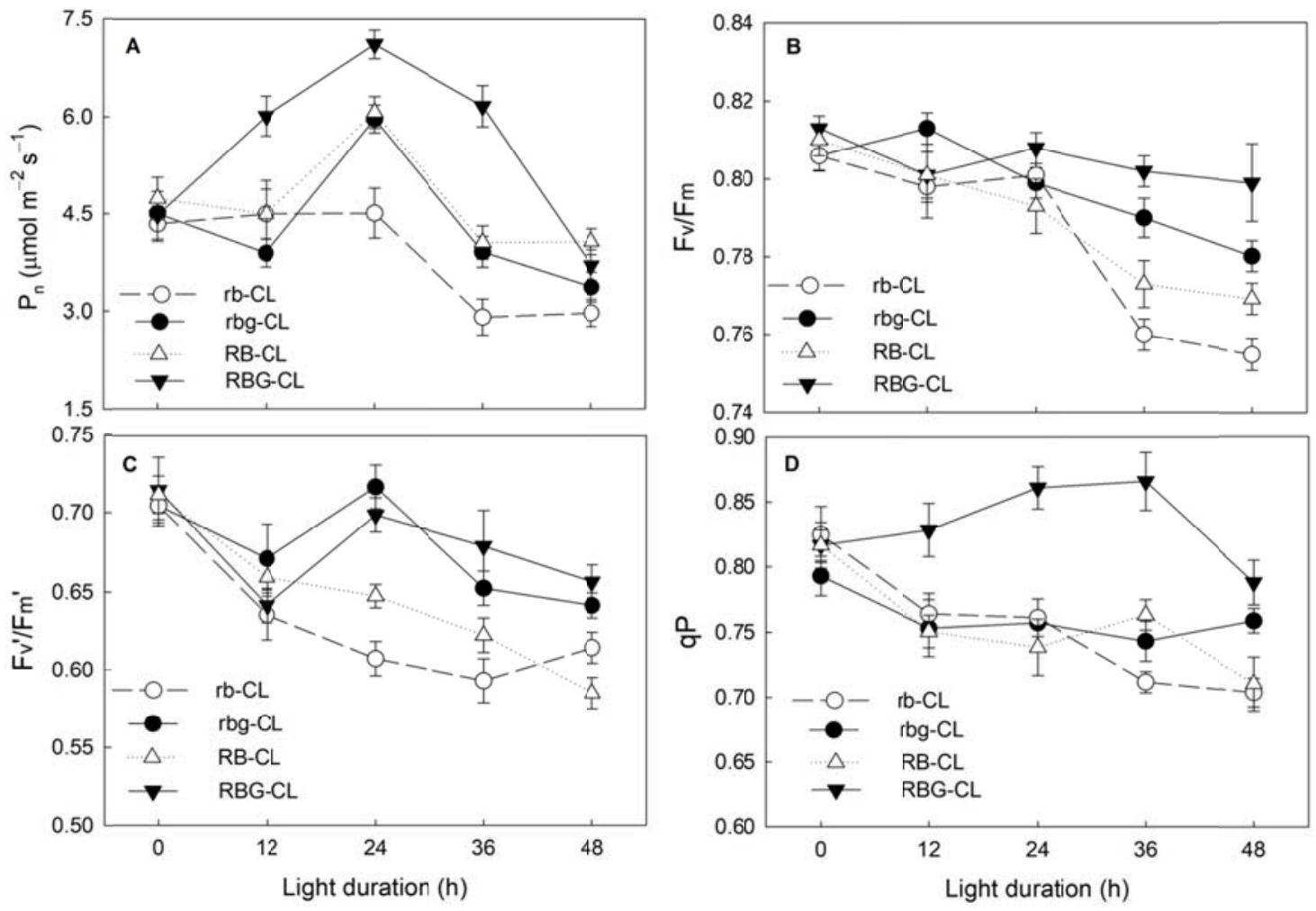

Fig. 3. Rate of total electron transport $\left(\mathrm{J}_{\mathrm{PSII}}, \mathrm{A}\right)$, light-dependent thermal dissipation $\left(\mathrm{J}_{\mathrm{NPQ}}, \mathrm{B}\right)$, light-independent thermal dissipation $\left(\mathrm{J}_{\mathrm{fD}}, \mathrm{C}\right)$ and excess energy (D) in leaves in response to continuous light $(C L)$. Data points indicate the mean \pm SE $(n=4$ or 6$)$. 

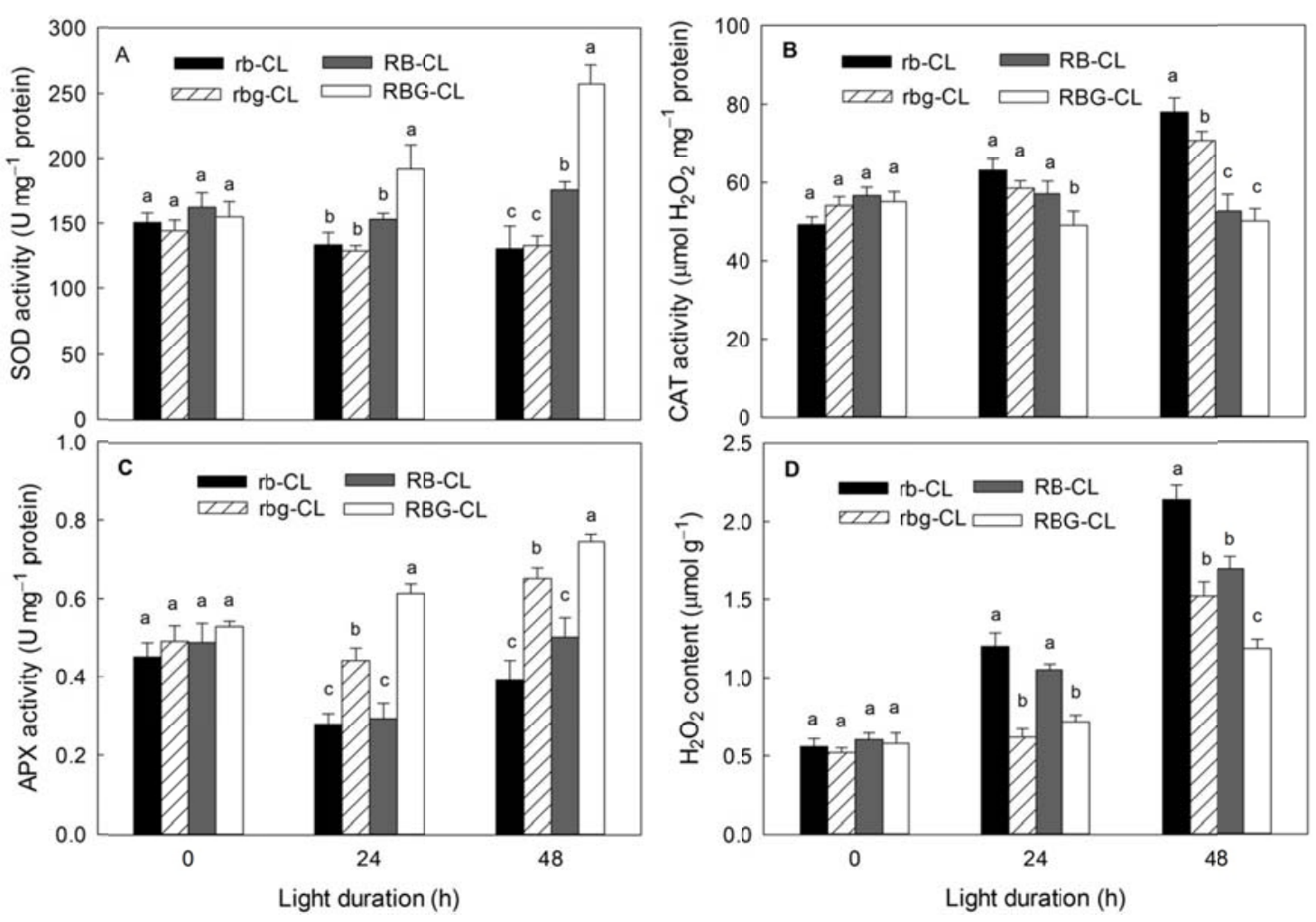

Fig. 5. Changes in MDA content in lettuce leaves under continuous light (CL). Data points indicate the mean $\pm \operatorname{SE}(n=4)$.

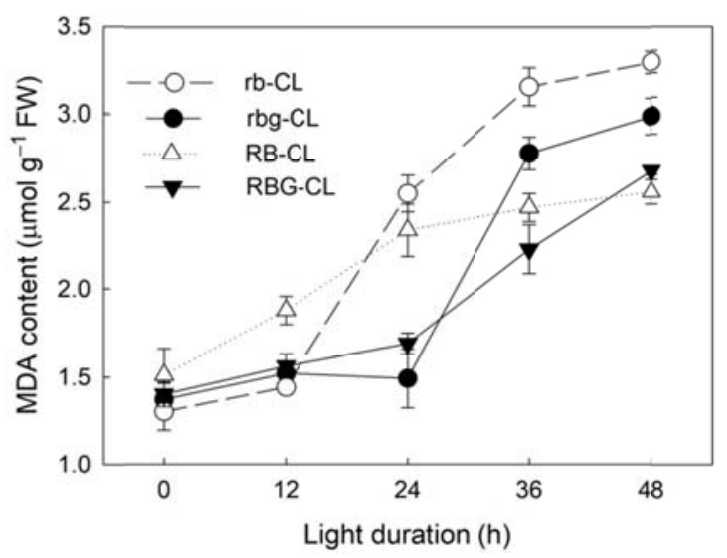

Fig. 6. Expression levels of the PsbA (A) and $L H C b$ (B) in response to continuous light (CL). The expression of the lettuce ACTIN gene at each time point was used as a reference. Data points indicate the mean \pm SE $(n=4)$. 

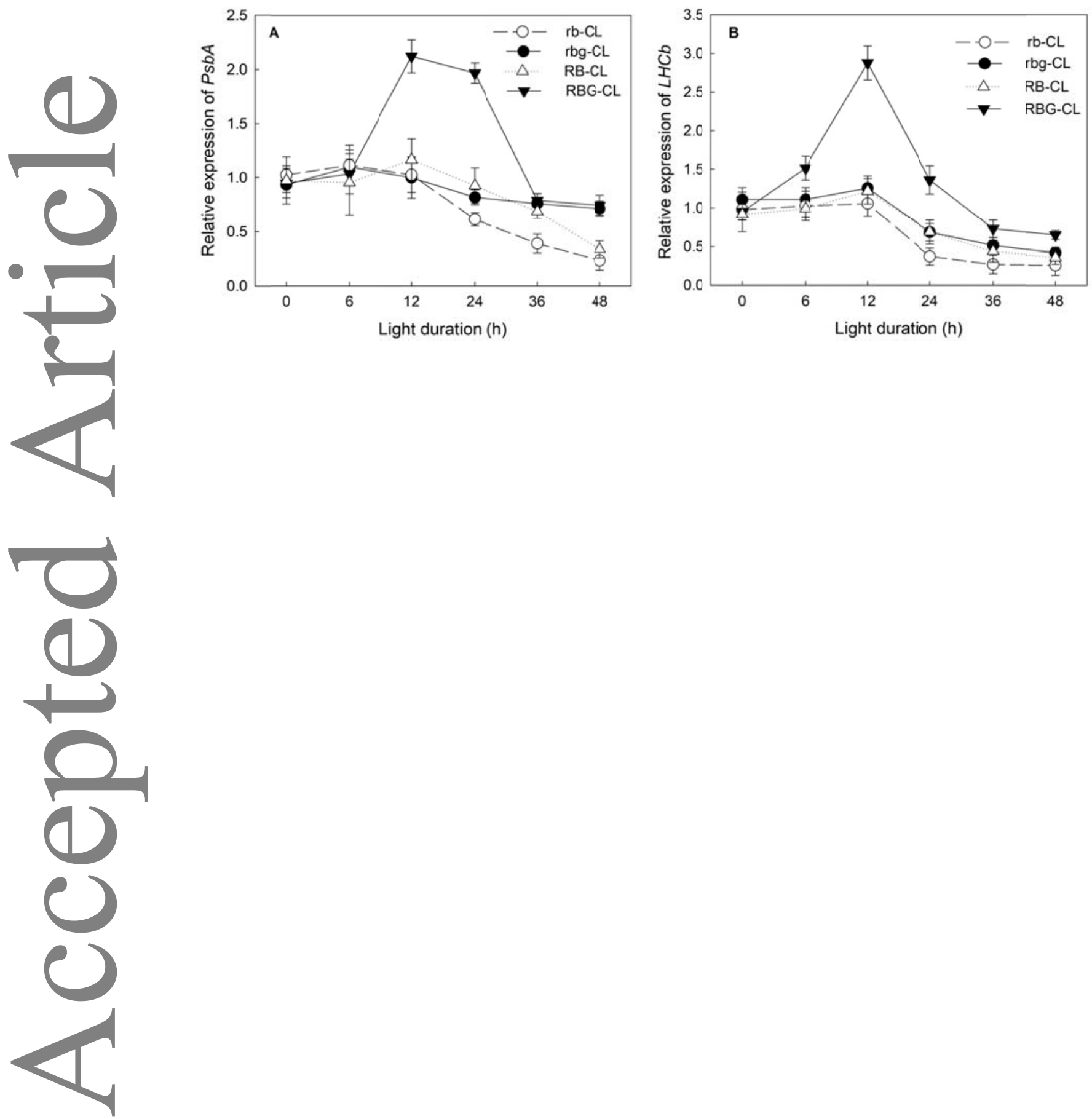
Table 1. List of light spectral data and light duration applied in the continuous light treatment. The light intensity of all treatments during the experiment was $200 \mu \mathrm{mol} \mathrm{m} \mathrm{m}^{-2} \mathrm{~s}^{-1}$. Before light treatment, the photoperiod in all the treatments was $12 \mathrm{~h}$. R, red light; B, blue light; G, green light; CL, continuous light.

\begin{tabular}{lllll}
\hline & $\begin{array}{l}\text { Before light treatment } \\
\text { (from transplanting until the light } \\
\text { Treatments }\end{array}$ & $\begin{array}{l}\text { Light treatment } \\
\text { (reatment) }\end{array}$ & $\begin{array}{l}\text { (from the end of the dark period until 20 } \\
\text { d after transplanting) }\end{array}$ \\
\cline { 2 - 5 } & Light source & $\begin{array}{l}\text { Light quality } \\
\text { ratio }\end{array}$ & Light source & Light quality ratio \\
\hline $\begin{array}{l}\text { RB-CL } \\
\text { RBG-CL }\end{array}$ & RB LEDs & R:B=4:1 & RB LEDs & R:B $=4: 1$ \\
rbg-CL & RBG LEDs & R:B:G=1:1:1 & RBG LEDs & R:B:G $=4: 1: 1$ \\
rb-CL & RBG LEDs & R:B:G $=1: 1: 1$ \\
\end{tabular}


Table 2. Leaf area, leaf number, leaf mass per area (LMA), shoot and root fresh weight and total fresh weight of lettuce before $(0 \mathrm{~h})$ and after $(48 \mathrm{~h})$ continuous light treatment. Data represent mean \pm SE $(\mathrm{n}=8)$. Different letters indicate significant differences between treatments $(P<0.05)$.

\begin{tabular}{|c|c|c|c|c|c|c|c|}
\hline Time & & & Leaf & LMA & Total fresh & \multicolumn{2}{|c|}{ Fresh weight (g) } \\
\hline (h) & 1Неатпен & area $\left(\mathrm{cm}^{2}\right)$ & number & $\left(\mathrm{g} \mathrm{m}^{-2}\right)$ & weight (g) & Shoot & Root \\
\hline & rb-CL & $337.3 \pm 40.7^{\mathrm{a}}$ & $13.0 \pm 0.40^{\mathrm{a}}$ & $22.5 \pm 2.4^{\mathrm{a}}$ & $16.3 \pm 0.95^{\mathrm{a}}$ & $14.1 \pm 0.95^{\mathrm{a}}$ & $2.2 \pm 0.25^{\mathrm{b}}$ \\
\hline 0 & rbg-CL & $325.3 \pm 36.6^{\mathrm{a}}$ & $13.3 \pm 0.43^{\mathrm{a}}$ & $19.7 \pm 3.3^{\mathrm{a}}$ & $16.1 \pm 0.82^{\mathrm{a}}$ & $14.3 \pm 0.64^{\mathrm{a}}$ & $1.8 \pm 0.25^{\mathrm{b}}$ \\
\hline & RB-CL & $332.8 \pm 39.9^{\mathrm{a}}$ & $15.0 \pm 0.47^{\mathrm{a}}$ & $21.1 \pm 2.7^{\mathrm{a}}$ & $16.9 \pm 0.79^{\mathrm{a}}$ & $14.5 \pm 0.40^{\mathrm{a}}$ & $2.4 \pm 0.51^{\mathrm{a}}$ \\
\hline & RBG-CL & $321.5 \pm 36.0^{\mathrm{a}}$ & $14.5 \pm 0.47^{\mathrm{a}}$ & $22.4 \pm 3.1^{\mathrm{a}}$ & $17.3 \pm 0.81^{\mathrm{a}}$ & $14.8 \pm 1.1^{\mathrm{a}}$ & $2.5 \pm 0.34^{\mathrm{at}}$ \\
\hline & rb-CL & $363.3 \pm 30.4^{b}$ & $13.8 \pm 0.70^{\mathrm{a}}$ & $29.7 \pm 1.6^{\mathrm{b}}$ & $22.3 \pm 0.68^{\mathrm{c}}$ & $20.0 \pm 1.3^{\mathrm{b}}$ & $2.4 \pm 0.54^{\mathrm{b}}$ \\
\hline 48 & rbg-CL & $394.8 \pm 17.2^{\mathrm{a}}$ & $14.5 \pm 0.49^{\mathrm{a}}$ & $29.1 \pm 2.3^{\mathrm{b}}$ & $25.1 \pm 0.65^{\mathrm{b}}$ & $22.4 \pm 1.0^{\mathrm{b}}$ & $2.7 \pm 0.26^{\mathrm{b}}$ \\
\hline & RB-CL & $406.5 \pm 19.2^{\mathrm{a}}$ & $15.3 \pm 0.52^{\mathrm{a}}$ & $31.6 \pm 2.8^{\mathrm{ab}}$ & $25.4 \pm 0.90^{\mathrm{ab}}$ & $21.9 \pm 1.2^{\mathrm{b}}$ & $3.5 \pm 0.63^{\mathrm{a}}$ \\
\hline & RBG-CL & $427.3 \pm 19.7^{\mathrm{a}}$ & $15.8 \pm 0.43^{\mathrm{a}}$ & $35.3 \pm 1.5^{\mathrm{a}}$ & $27.5 \pm 0.50^{\mathrm{a}}$ & $24.3 \pm 0.80^{\mathrm{a}}$ & $3.2 \pm 0.19^{2}$ \\
\hline
\end{tabular}

